\title{
Comparisons of sponge populations across the Barrier Reefs of Australia and Belize: evidence for higher productivity in the Caribbean*
}

\author{
Clive R. Wilkinson, Anthony C. Cheshire** \\ Australian Institute of Marine Science, PMB No. 3, Townsville M.C., Queensland 4810, Australia
}

\begin{abstract}
Sponge populations were compared along transects from land-influenced, inner-shelf reefs to ocean-influenced reefs of the 2 largest barrier reefs in the Pacific and Atlantic Oceans. Sponge biomass on Belize reefs in the Caribbean is greater than on comparable reefs of the central Great Barrier Reef (GBR), whereas individual abundance and species richness are similar in the 2 regions. Inner-shelf sponge populations are comparable in trophic structure with approximately twice as much biomass and rate of carbon consumption on Belize reefs. Sponge populations on clean water reefs of the 2 regions, however, are fundamentally different. With approximately 6 times the biomass, Belize sponges are large and almost totally heterotrophic and consume on average 15 times more organic carbon per unit area than GBR sponge populations, of which ca $50 \%$ of the biomass consists of small phototrophic species. The fundamental differences in species composition and mode of nutrition of the sponge populations are a result of long temporal and spatial separations of the 2 regions. The difference in abundance of phototrophic sponges follows a pattern of a greater evolution of symbioses in the more oligotrophic Pacific Ocean. The greater sponge biomass and rates of carbon consumption on these Caribbean reefs are suggestive of higher oceanic productivity compared with that of the Pacific. Increases in the biomass of heterotrophic sponges are proposed as an early warning signal for organic pollution on coral reefs.
\end{abstract}

\section{INTRODUCTION}

The 2 largest barrier reets in the eastern and western hemispheres differ in size by an order of magnitude. The Great Barrier Reef (GBR) is over $2300 \mathrm{~km}$ long with almost 3400 separate reefs (including 750 fringing reefs) over a continental shelf varying in width from 24 to $290 \mathrm{~km}$, whereas the Belize Barrier Reef complex

\footnotetext{
- Contribution No. 510 from the Australian Institute of Marine Science

- Present address: Botany Department, University of Adelaide, Adelaide, South Australia 5001. Australia
}

in the Caribbean is $250 \mathrm{~km}$ long with many fewer reefs over a much narrower shelf (10 to $32 \mathrm{~km}$ wide).

The appearance of these 2 reef systems is strikingly different because of markedly different species compositions of coral reef animals in the 2 oceans. There are few or no species of sponges, corals and molluscs which co-occur on the GBR and Belize reefs (Vermeij 1978, Rosen 1981, Wilkinson 1987). Some differences are readily apparent, e.g. the prominence of soft (Alcyonacean) corals on the GBR in contrast to the abundance of gorgonians on Caribbean reefs (Porter 1974, Rosen 1981). Some absences are also particularly striking, e.g. there are no fungiid corals, tridacnid clams or Acanthaster planci in the Atlantic. 
There are, however, distinct similarities in the functional responses of the 2 reef systems. Kinsey (1982, 1983) has shown that the metabolic rates of primary production and calcification in the 2 reef provinces are remarkably similar, indicating that the end result is the same although many of the 'players' are different.

The compositional differences are due to long temporal and geographical separation of the reefs. The 2 oceans were definitively isolated approximately 3 to 5 million years ago, but for a long time before that they were in effect isolated by $15000 \mathrm{~km}$ of deep ocean with very few, widely spaced islands and reefs in between (Woodring 1966, Vermeij 1978). Many of the species in the 2 oceans have evolved different life strategies to cope with or better utilize the environmental conditions (Vermeij 1978, Hallock 1988). For example, Caribbean reef fishes have smaller pelagic eggs which was regarded as an adaptation to the higher content of suspended food matter in Atlantic waters compared to the Pacific (Thresher 1982, Victor 1986). The presence of almost totally heterotrophic sponge populations in the Caribbean also correlates with this presumed higher nutrient content (Highsmith 1980, Wilkinson 1987).

Caribbean sponge populations have ca 5 times the biomass $\left(\mathrm{kg} \mathrm{m}^{-2}\right)$ but consume ca 10 times more organic matter $\left(\mathrm{g} \mathrm{m}^{-2}\right)$ than sponge populations on corresponding reefs of the GBR because many of the sponges on GBR reefs are phototrophic and essentially self sustaining for much of their carbon energy requirements (Wilkinson 1987).

Differences in the consumption of organic matter by sponge populations on continental shelf reefs of the 2 oceans were hypothesized to occur based upon the quantitative differences in the biomass and fundamental differences in the predominant mode of nutrition of sponges in the 2 regions. To test this hypothesis, we compared sponge populations on reefs across the continental shelves of the 2 large barrier reef systems. Data on sponge populations and rates of consumption on 12 reefs across the central GBR are reported elsewhere (Wilkinson \& Trott 1985, Wilkinson \& Cheshire 1989 , Cheshire \& Wilkinson in press) and summarized here for comparison with surveys performed on 3 reefs across the Belize Barrier Reef at similar latitudes (around $18^{\circ} \mathrm{S}$ and $\mathrm{N}$ respectively).

\section{MATERIALS AND METHODS}

Data on sponge populations across the shelf of the GBR have been published in Wilkinson \& Trott (1985) and Wilkinson \& Cheshire (1989). These data report sponge biomass, abundance and species richness at depths from 2 to $20 \mathrm{~m}$ on 2 inner-shelf reefs, 4 middleshelf reefs, 3 outer-shelf reefs (across the continental shelf of the central GBR between Latitudes $18^{\circ}$ and $19^{\circ} \mathrm{S}$ ) and 3 oceanic reefs of the Flinders Reefs in the
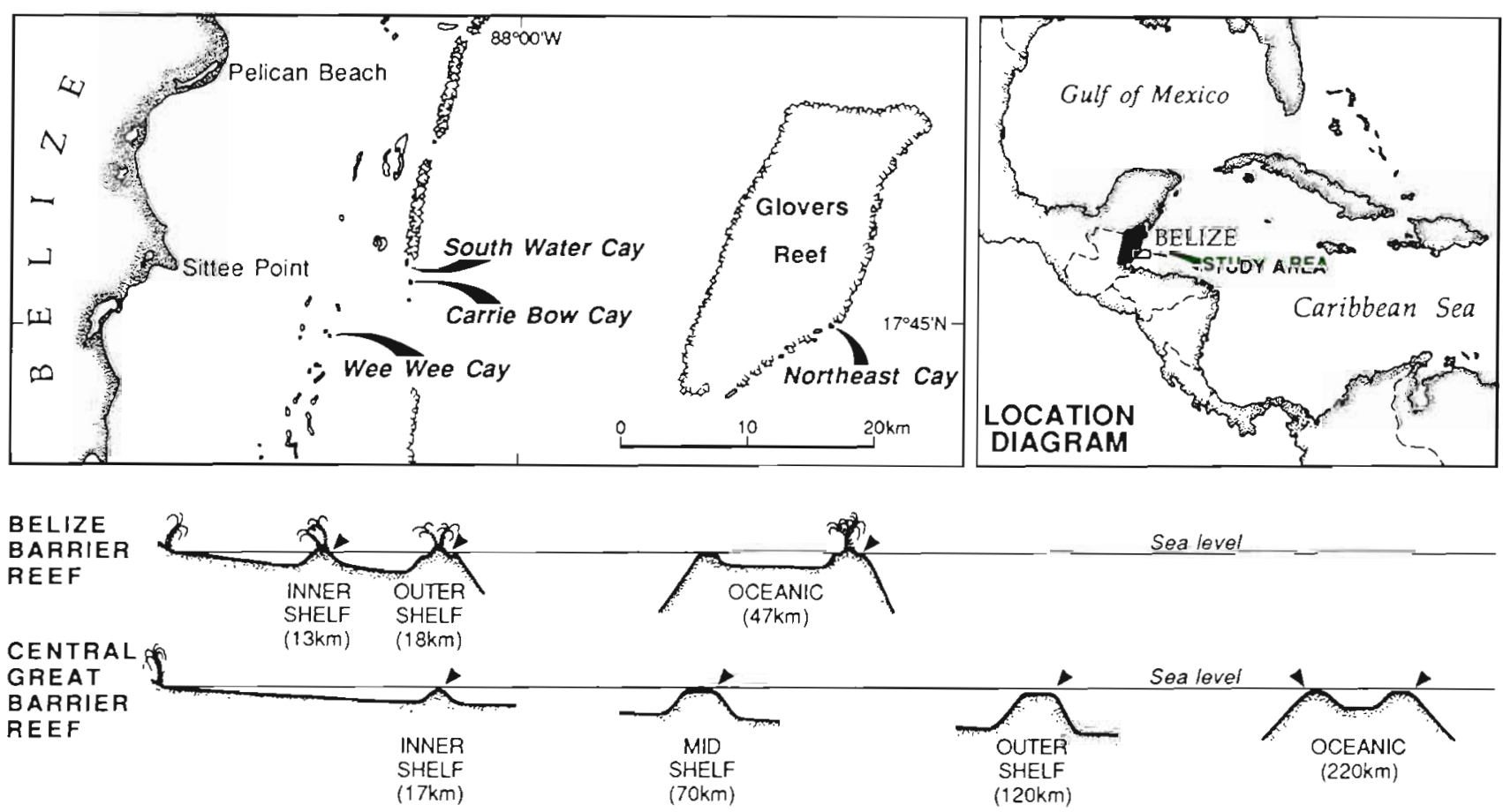

Fig. 1. Map and stylized vertical cross-section across the Belize Barrier Reef showing the study sites at Wee Wee, South Water, and Northeast Glovers cays. A cross-section of the central Great Barrier Reef at the same scale is included for comparison. Maps ot the central GBR can be found in Wilkinson \& Trott (1985), Wilkinson (1986), Wilkinson \& Cheshire (1989) 
Coral Sea. The Belize (Fig, 1) surveys were conducted at 5, 10, 15 and $20 \mathrm{~m}$ on the seaward facing slopes of Wee Wee Cay, $\left(16^{\circ} 44^{\prime} \mathrm{N}, 88^{\circ} 08^{\prime} \mathrm{W}\right.$; an inner-shelf reef, $13 \mathrm{~km}$ from the coast of Belize), South Water Cay $\left(16^{\circ} 49^{\prime} \mathrm{N}, 88^{\circ} 05^{\prime} \mathrm{W}\right.$, on the edge of the continental shelf, $18 \mathrm{~km}$ from the coast and $1.5 \mathrm{~km} \mathrm{~N}$ of the Smithsonian Institution field station on Carrie Bow Cay), and Northeast Cay, Glovers Reef $\left(16^{\circ} 45^{\prime} \mathrm{N}, 88^{\circ} 15^{\prime} \mathrm{W}\right.$, an oceanic reef, $47 \mathrm{~km}$ off the coast and separated from the continental shelf by water in excess of $300 \mathrm{~m}$ deep). Triplicate $40 \mathrm{~m}^{2}$ surveys were conducted along the depth profile at each depth. All sponges, except boring, thin encrusting and cryptic species were collected, sorted and weighed (Wilkinson \& Trott 1985). Surveys on Wee Wee Cay at 10 and $15 \mathrm{~m}$ were limited to $8 \mathrm{~m}^{2}$ because of the large number and volume of sponges. Any additional species that occurred in the remaining $32 \mathrm{~m}^{2}$ were recorded. Very large specimens of Xestospongia muta were not collected, but the weights were estimated by calculating the volume from linear measurements and using a weight/volume correction factor calculated from smaller specimens or parts of larger animals which were weighed. Such estimates were made conservatively, erring on the side of underestimation.

Specimens of the most prominent sponges (79 individuals, 20 species), in terms of both biomass and abundance, were screened for oxygen consumption in the dark and light by the instantaneous method reported in Wilkinson $(1982,1983)$. Specimens were incubated in a $1 \mathrm{l}$ chamber at 50,100,200,300,400 and $600 \mu \mathrm{E} \mathrm{m}^{-2} \mathrm{~s}^{-1}$ for $20 \mathrm{~min}$ alternating light and dark periods.

In order to calculate the amount of organic carbon consumed by the Belize sponges, a photosynthetic ratio of $1: 1$ ( $\mathrm{mol} \mathrm{O}_{2}$ to organic carbon) was used (Wilkinson 1983) and it was also assumed that the average respiration rate of the heterotrophic sponges was similar to that calculated during instantaneous respirometric measurements of GBR sponges: 63 (55 to 70, 95\% CL) $\mu \mathrm{g} \mathrm{O}_{2} \mathrm{~g}^{-1}$ wet wt $\mathrm{h}^{-1} ; 79$ specimens (Cheshire \& Wilkinson in press). This contrasts with the results of Wilkinson (1987: $44.5 \mu \mathrm{g} \mathrm{O}_{2} \mathrm{~g}^{-1} \mathrm{~h}^{-1}, 20$ specimens) on Belize sponges but due to the large variance in the data set these results are not significantly different. In the calculations of total consumption, both heterotrophic and mixotrophic sponges (sensu Wilkinson \& Trott 1985) have been pooled because there was no significant difference between dark and light respiration rates in the mixotrophs during oxygen exchange measurements.

The net $24 \mathrm{~h}$ productivity rates for phototrophic sponges on the GBR are those determined from the model of Cheshire \& Wilkinson (in press) of $0.31 \mathrm{mg}$ $\mathrm{C} \mathrm{g}^{-1}$ wet wt $\mathrm{d}^{-1}$ at $2 \mathrm{~m}$ decreasing to $0.18 \mathrm{mgC} \mathrm{g}^{-1} \mathrm{~d}^{-1}$ at $20 \mathrm{~m}$, assuming a $12: 12 \mathrm{~h}$ light:dark cycle with maximal surface light at solar noon of $1800 \mu \mathrm{E} \mathrm{m} \mathrm{m}^{-2} \mathrm{~s}^{-1}$.

Differences in biomass, abundance and species richness of sponge communities between sites and regions were assessed in a series of 2-way ANOVAS. Data were normalized as follows: natural logarithm transformation for biomass; square root transformation for abundance and species. Subsequent a posteriori location of differences between specific subsets was undertaken using a Scheffe test.

\section{RESULTS}

Sponge biomass on the fore-reef slopes of reefs across the Belize continental shelf shows a significant relationship to depth at each location. The biomass is low in water shallower than $10 \mathrm{~m}$ and increases towards the maximum depth surveyed of 15 or $20 \mathrm{~m}$ $(p<0.02$, multiple regression; Fig, 2$)$. The increase in biomass with depth is comparable with that observed on reefs of the Great Barrier Reef where maximal populations occur between 15 and $20 \mathrm{~m}$ on the forereef slopes (Wilkinson \& Trott 1985, Wilkinson \& Cheshire 1989).

There is a distinct trend in sponge populations across the Belize continental shelf with higher biomass, abundance and species richness nearer the land than in oceanic waters (Fig. 3, Table 2). The inner-shelf reef, Wee Wee Cay, had significantly higher sponge biomass $(p<0.01)$, abundance $(p<0.001)$, and species richness $(p<0.01)$ than either the outer-shelf or the oceanic reefs (South Water Cay and NE Glovers Reef, Table 2).

The slopes of South Water Cay had a significantly lower biomass $(p<0.05)$ but similar abundance of sponges compared to the Glovers Reef site, ca $30 \mathrm{~km}$ further offshore. Unlike the other Belize reefs, South Water Cay has a comparable biomass of sponges and significantly lower abundance $(p<0.01)$ when compared to the equivalent (outer-shelf) reefs of the GBR. This apparent reduction is probably a consequence of Hurricanes Hattie (October 1961), Fifi (September 1974) and Greta (September 1978) which caused considerable damage directly to Carrie Bow and South Water Cays (Stoddart 1974, Rutzler \& Ferraris 1982) and probably destroyed sponges on these exposed slopes. Recovery would be slow as Caribbean sponges generally have slow growth rates (Wilkinson \& Cheshire 1988).

Across the shelf of the central GBR there is a similar trend with significantly more sponge biomass on innershelf reefs than middle- or outer-shelf reefs, which are in turn significantly greater than oceanic reefs (Table 1; Wilkinson \& Cheshire 1989). Virtually all of the 
Table 1. Biomass, abundance and species richness of sponge populations on reefs across the Belize continental shelf (") compared with sponge populations on reefs at similar shelf locations on the Great Barrier Reef. Data are means of 3 transects, each $40 \mathrm{~m}^{-2}$

IS: inner-shelf; OS: outer-shelf; Oc: oceanic; - no data available. Analysis of variance tests are given in the footnotes

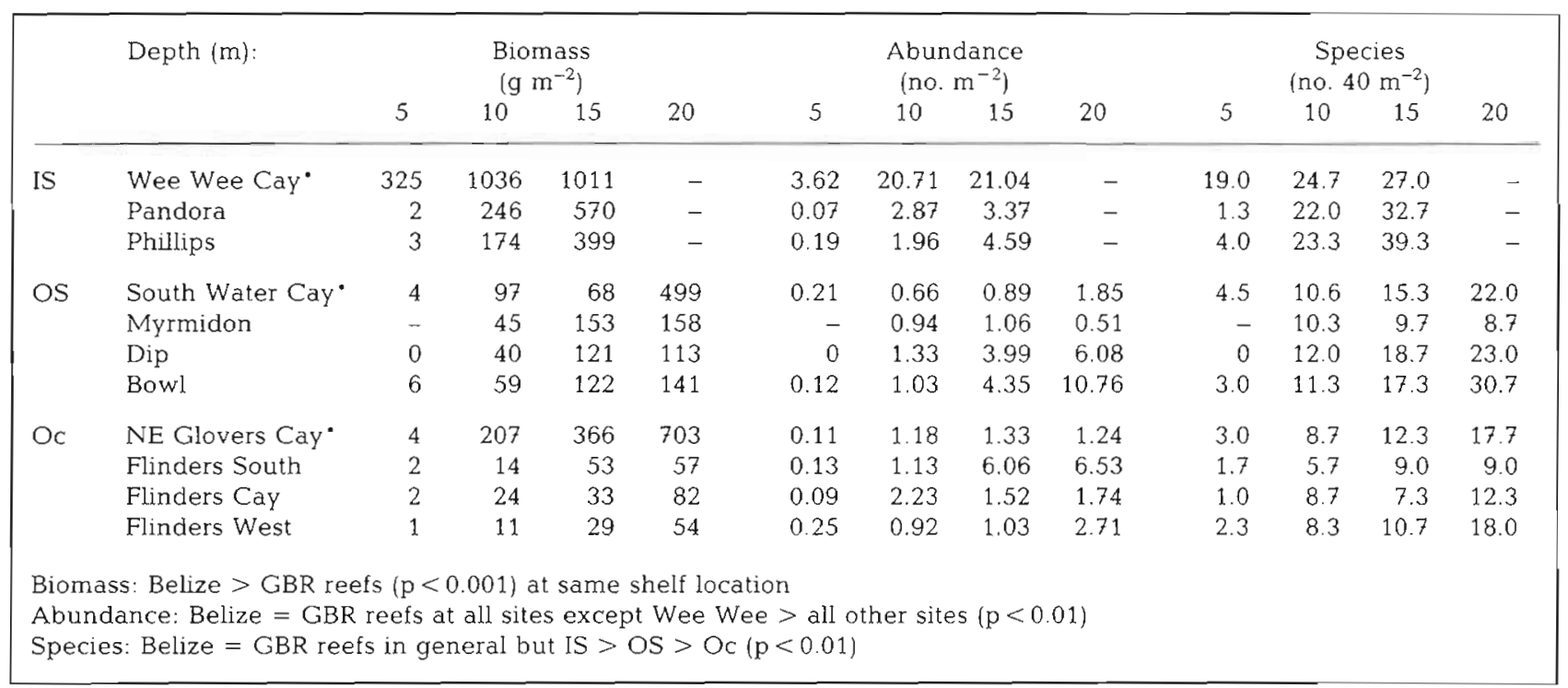

sponges on these Belize reefs are heterotrophic in their nutritional requirements. Totally heterotrophic (no photosynthetic symbionts) sponges constitute a large proportion (ca $69 \%$ inner-, $51 \%$ outer-shelf, $24 \%$ oceanic) of total sponge biomass. The most prominent of these are Pseudoceratina crassa, Ectyoplasia ferox, tubular Agelas sp. B (in Colin 1978, p. 57), A. dispar and Callyspongia vaginalis. The remainder are mixotrophs in which only a small proportion of the tissue contains symbiotic cyanobacteria. The most prominent of these are Xestospongia muta, Hymeniacidon sp., Geodia neptuni, Ircinia felix, I. strobilina, Aplysina

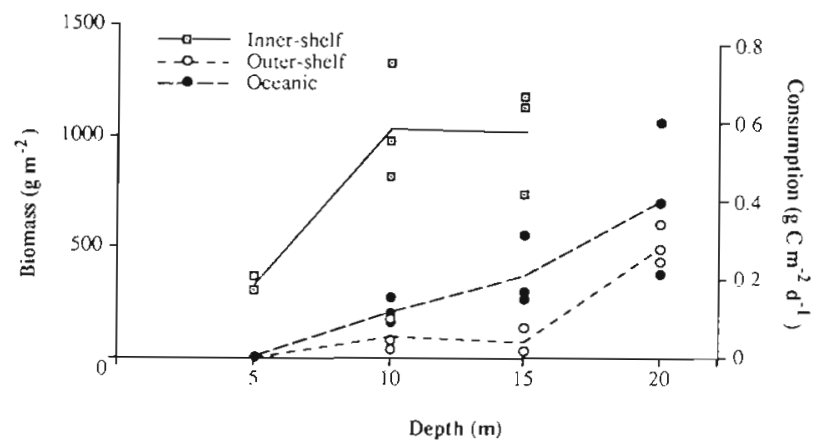

Fig. 2. Sponge biomass and the amount of carbon consumed by sponge populations at different depths on 3 Belize reefs (inner-shelf, Wee Wee Cay, $13 \mathrm{~km}$ from land; outer-shelf, South Water Cay, $18 \mathrm{~km}$; oceanic, NE Glovers Cay, $47 \mathrm{~km}$ ) Biomass and carbon consumption are almost directly related by the ratio of ' $1 \mathrm{~g}$ wet wt sponge consumes $0.548 \mathrm{mg}$ organic $\mathrm{C} \mathrm{d}^{-1}$. The amount of production by symbiotic cyanobacteria in the mixotrophs was not considered as it was barely detectable in instantaneous respirometric measures $(<5 \%$ of the consumption rate\} cauliformis, $A$. archeri, and A. fulva. No phototrophic sponges (except zooxanthellae-containing boring sponges] were found on the Belize reef transects.

This pattern of predominance of heterotrophic and mixotrophic sponges is only found on the inner-shelf reefs of the GBR (biomass at $15 \mathrm{~m}=63 \%$ heterotrophic and $37 \%$ mixotrophic). On outer-shelf and oceanic reefs of the GBR, phototrophic sponges are particularly prevalent and there is a far lower proportion of totally heterotrophic sponges (biomass at $20 \mathrm{~m}=$ outer-shelf on $44 \%$ heterotrophic, $16 \%$ mixotrophic, $40 \%$ phototrophic; oceanic $=26,6$ and $68 \%$, respectively; Wilkinson \& Cheshire 1989).

When 9 mixotrophic and 11 heterotrophic sponge species from the Belize reefs were screened for oxygen exchange, there was no significant increase above the dark respiration rate on exposure to a light intensity of $600 \mu \mathrm{E} \mathrm{m}^{-2} \mathrm{~s}^{-1}$; equivalent to full midday sunlight in 10 to $15 \mathrm{~m}$ on a clear summer day. Therefore photosynthetic productivity was ignored in calculating the amount of carbon consumed by these sponge populations.

The sponge populations between 10 and $20 \mathrm{~m}$ depth on these Belize reefs consume between 40 and $600 \mathrm{mgC} \mathrm{m}^{-2} \mathrm{~d}^{-1}$ (Fig. 2). The largest populations on Wee Wee Cay, a land-influenced inner-shelf reef only $13 \mathrm{~km}$ from the coast consume the largest amount. The rates on the NE reef of the Glovers Reef complex, $47 \mathrm{~km}$ from land in clean Caribbean waters, are ca 30 to $50 \%$ of those on the inner-shelf reef.

The sponge biomass below $5 \mathrm{~m}$ on the Belize Reefs is ca 2 to 12 times larger than that found on reefs at a comparable shelf-location on the central GBR (Fig. 3). 


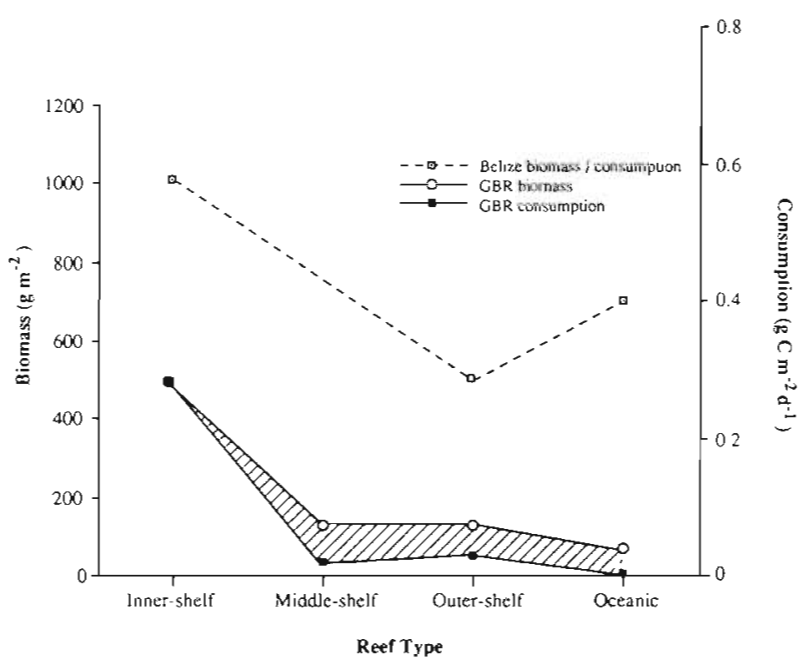

Fig. 3. Comparison of sponge biomass and organic carbon consumption by sponge populations of reefs across the continental shelves of the central Great Barrier Reef and Belize measured at the depth of maximal occurrence $(15$ or $20 \mathrm{~m}$ ). The upper 2 curves record the total biomass (left axis) of sponges in the 2 regions. All 3 curves record real and hypothetical organic carbon consumption (right axis) by these sponges. Upper: real consumption by heterotroph and mixotroph sponges of Belize; lower: real net consumption by the total GBR sponge populations including phototrophs; middle: hypothetical GBR consumption as an extrapolation of night respiration rates for $24 \mathrm{~h}$ (i.e. ignoring the photosynthetic contribution); hatched area: significant contribution made by phototrophic sponges to the carbon consumption balance of GBR sponges. The $95 \%$ confidence limits are ca $12 \%$ on either side of the lines

The differences in the amount of organic carbon consumed on reefs in the 2 systems are greater than the corresponding variations in the biomass.

Sponges at $20 \mathrm{~m}$ on outer-shelf and oceanic reefs of Belize consume significantly more organic carbon than reefs with comparable shelf locations (mean of pooled reefs) of the GBR (net consumption outer-shelf $=283$ vs $39 \mathrm{mgC} \mathrm{m} \mathrm{m}^{-1}=$ ratio $=7.3: 1 ;$ oceanic $=399 \mathrm{vs}$ $6 \mathrm{mgC} \mathrm{m}^{-2} \mathrm{~d}^{-1}$, ratio $=66.5: 1 ;$ Fig. 3). This is in comparison to the relative biomass differences of 3.6:1 and 11.0:1 between outer-shelf and oceanic reefs of the 2 oceans respectively (outer-shelf $=499 \mathrm{vs} 137 \mathrm{~g}$ wet wt $\mathrm{m}^{-2}$; oceanic $=703$ vs $64 \mathrm{~g} \mathrm{~m}^{-2}$ ).

In comparison, the ratio between biomass and carbon consumption on the inner-shelf reefs is the same because the sponges in the 2 regions are almost totally heterotrophic (Caribbean vs GBR biomass $=1011$ vs $484 \mathrm{~g}$ wet $\mathrm{wt} \mathrm{m}^{-2}$, ratio $=2.09: 1$; net consumption $=$ 573 vs $275 \mathrm{mgC} \mathrm{m}^{-2} \mathrm{~d}^{-1}$, ratio $=2.08: 1$ ).

The explanation for these marked differences between the biomass and carbon consumption of the oceanic and outer-shelf reefs of the 2 barrier reefs, lies in the presence of ca $50 \%$ (5 to $97 \%$ ) of phototrophic sponges on the GBR at $20 \mathrm{~m}$ (Wilkinson 1987). These differences are represented as the discrepancy between the net $24 \mathrm{~h}$ consumption rate of the sponge population (lowest line Fig. 3) and a rate calculated for the same period assuming that all of these sponges continue to respire at the night rate throughout the full day (as if they were totally heterotrophic, middle line).

On the clean-water reefs of the GBR (all except inner-shelf) the sponge populations are almost at compensation point, i.e. consumption of organic carbon is nearly matched by the amount of primary productivity from the photosynthetic symbionts (lower line, Fig. 3). These calculations were made for equinox seasons, therefore this pattern would vary between the seasons, with summer production being higher and winter production being lower because of the reduced ambient light and day length.

There is no significant difference in species richness between the 2 barrier reef systems. Differences that do occur between reefs have a greater within-system variance than between (Table 2). There are no species that are common to the 2 regions.

The combination of larger sponge biomass on the Belize reefs and the similarity in sponge abundance means that the average size of sponges is much larger on the Belize reefs. This is obvious to a diver with the large verongids (Verongula gigantea, Aplysina archeri), Agelas sp. B, Geodia neptuni and especially the massive Xestospongia muta being particularly striking. Average sponge weight at the deepest site on inner-, middle-, outer-shelf and oceanic reefs of the GBR is $122,26,24$ and $18 \mathrm{~g}$, respectively; whereas on Belize inner-, outer-shelf and oceanic reefs, the average weight is 48,269 and $567 \mathrm{~g}$.

\section{DISCUSSION}

There are fundamental differences in the nature and size of sponge populations on reefs across the continental shelves of the 2 major barrier reef systems. The species compositions are completely different in the 2 oceans, reflecting both long-lasting temporal and spatial separations of the Great Barrier Reef region (western Pacific Ocean) and the Belize Barrier Reef (Caribbean Seal. The other major differences are in the biomass and the nutritional strategies of the sponge populations in the 2 regions. These differences provide additional evidence that the 2 regions have fundamentally different evolutionary histories and their current levels of primary productivity are probably dissimilar.

The biomass of Belize sponge populations is ca 5 times greater than on comparable reefs of the GBR. This difference is accentuated if the amount of organic carbon consumed by these populations is compared, i.e. Belize sponges consume at least 10 times more 
organic carbon than comparable GBR sponge populations. Thus, the sponges at $20 \mathrm{~m}$ on outer-shelf and oceanic reefs of the GBR consume 0.1 to $0.5 \%$ of the gross primary productivity of an 'average' coral reef (7 $\mathrm{g} \mathrm{m}^{-2} \mathrm{~d}^{-1}$; Kinsey 1983); whereas sponges on outershelf and oceanic reefs of Belize consume 4 to $6 \%$ of this average primary productivity.

The differences in consumption rates by inner-shelf sponges between the 2 regions is less marked. Sponges at $15 \mathrm{~m}$ on inner-shelf reefs of the GBR consume about $4 \%$ of adjacent gross productivity, whereas similar sponges on Wee Wee Cay in Belize consume ca $8 \%$ of the productivity. This difference is directly attributable to the differences in the size of the sponge populations in the 2 regions, i.e. approximately double on innershelf reefs of Belize. On many of these reefs, however, the $7 \mathrm{~g} \mathrm{~m}^{-2} \mathrm{~d}^{-1}$ 'average' primary productivity would be augmented by inputs of organic matter from adjacent oceanic productivity and runoff from the land. Therefore, the percentages listed above should only be used for comparison purposes.

Reiswig (1974) has highlighted the significance of Caribbean sponges in the utilization of organic matter in coral reef waters. There is reasonably close agreement between his figures and those determined for the Belize sponges. In 1974, he calculated that the large sponge populations on the north coast of Jamaica could remove between 0.8 to $1.9 \mathrm{~g}$ particulate organic $\mathrm{C} \mathrm{m}^{-2}$ $\mathrm{d}^{-1}$ (11 to $27 \%$ of 'average' reef productivity). This was interpreted as the sponge fauna being able to filter a vertical water column of between 16.5 and $40 \mathrm{~m} \mathrm{~d}^{-1}$. Reiswig (1981) calculated that sponges with extensive

Table 2. Results from a posteriori Scheffe (specific subset) comparisons after a 2-way ANOVA comparing biomass ", abundance " and species richness $\cdots$ for the 3 shelf locations (IS, OS, OC) between both systems (Belize and GBR). Data from 10, 15 and $20 \mathrm{~m}$ at each site have been pooled. Only specific subsets have been compared: (1) between shelf locations within each reef system; and (2) between reef systems at the same shelf location. The nature of the difference and its significance are both shown in the comparison matrix. NS: not significant

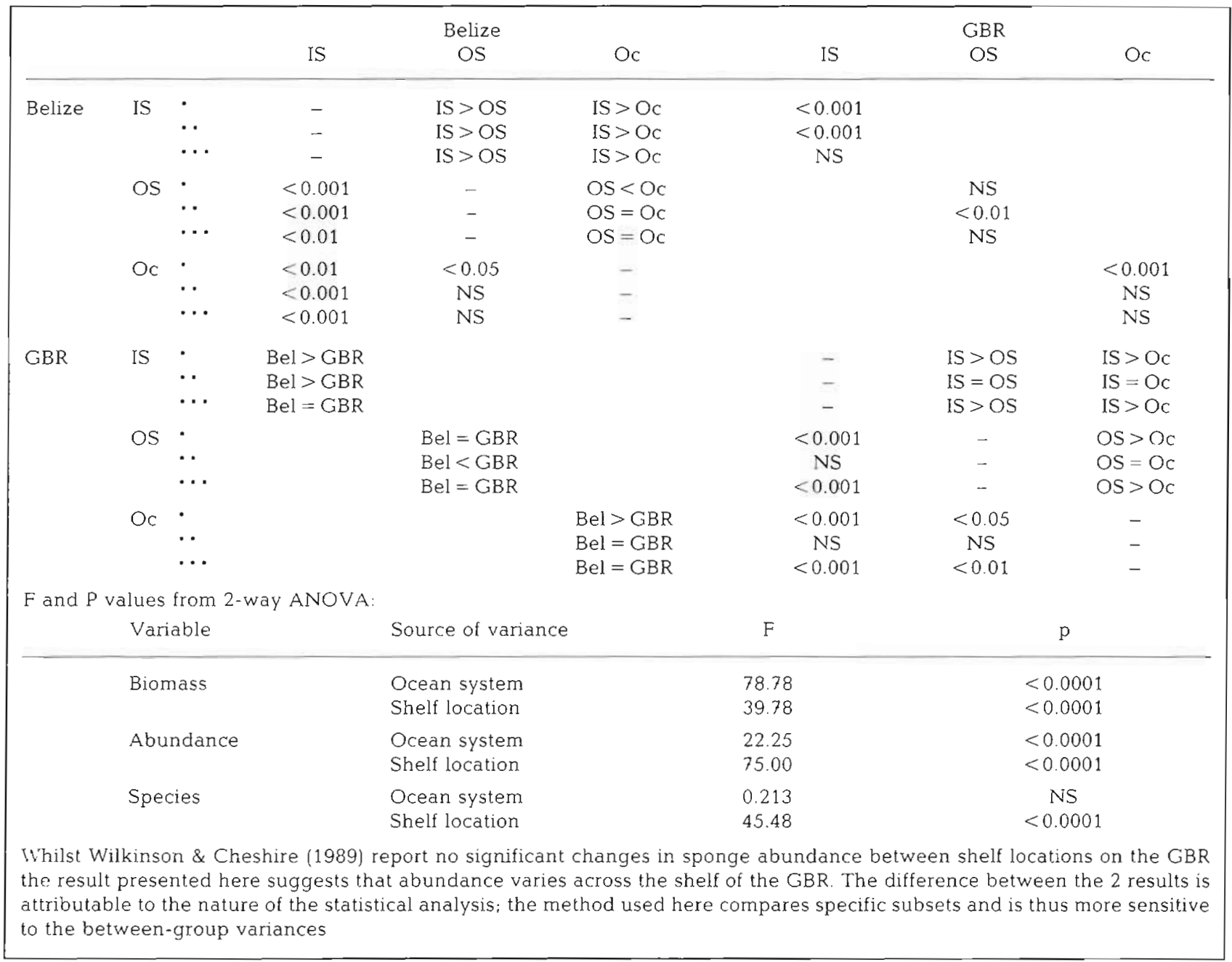


populations of symbiotic bacteria (Aplysina fistularis) required ca $1.04 \mathrm{mgC} \mathrm{g}^{-1}$ wet wt $\mathrm{d}^{-1}$ as particulate and dissolved organic carbon to balance respiratory requirements. This is approximately double that found in this study of $0.57 \mathrm{mgC} \mathrm{g}^{-1}$ wet wt $\mathrm{d}^{-1}$. The difference is attributed both to differences in the sponges studied and in the techniques used to measure sponge respiration rates. The $A$. fistularis from Barbados resemble some of the Aplysina spp. found on the outer reefs of Belize, but the Barbados sponges would be expected to have enhanced respiration rates because of the extensive populations of symbiotic, heterotrophic bacteria found in these Aplysina spp. (Reiswig 1981, Wilkinson et al. 1981). Reiswig collected exhalant water from large specimens in situ and measured oxygen content in the laboratory whereas the specimens we examined were much smaller and removed from the natural environment for continuous oxygen assay by electrodes in enclosed chambers.

The major differences in consumption rates by outershelf and oceanic-reef sponges between the 2 oceans are due to fundamental differences in the nutrition of the sponge populations. Caribbean reef sponges are almost totally heterotrophic (Wilkinson 1987) with none of the small phototrophic sponges that are so prevalent on clean-water reefs of the GBR. The most abundant sponges on the GBR are foliose dictyoceratids (Wilkinson 1988) and a few other flattened species which all have large populations of symbiotic cyanobacteria (Wilkinson \& Trott 1985, Wilkinson \& Cheshire 1989). Therefore, many of the sponges on the clean water reefs of the GBR are almost 'self sufficient' (Wilkinson 1983, Cheshire \& Wilkinson in press), with the amount of organic carbon added to the ecosystem by the phototrophs being almost equal to that removed by these sponges and the other heterotrophic and mixotrophic sponges (Fig. 3).

On the GBR, sponge biomass decreases across the shelf with a large biomass of predominantly heterotrophic sponges on inner-shelf reefs, and decreasing sponge biomass on reefs away from the land influence. This is in parallel with an increase in the proportion of phototrophic sponges (Wilkinson \& Trott 1985, Wilkinson 1986). There are no phototrophs on inner-shelf reefs whereas approximately $70 \%$ of the sponge biomass on Coral Sea reefs consists of phototrophic sponges, although the total biomass is 12 times lower than on inner-shelf reefs. There is a similar, but less distinct, cross-shelf trend with Belize sponges. The highest biomass occurs on Wee Wee Cay (an innershelf reef, Fig. 3) which is probably attributable to greater availability of land-derived organic matter and a lower incidence of destructive turbulence on these more protected reefs. The Belize reef sponges are unlike those on the GBR, in that there are no variations in the trophic structure of the sponge populations across the continental shelf.

Phototrophic sponges on the 'clean-water' reefs of the GBR have an additional mechanism for obtaining nutrition, thereby they have increased fitness to survive in these relatively low nutrient environments. Heterotrophic sponges are totally reliant on the availability of organic matter in the water column; therefore low sponge biomass is probably a direct reflection of low food availability. The phototrophs, however, do not have this reliance, and are able to grow in clear tropical waters using translocated photosynthetic products to augment the organic matter obtained by filter feeding (Wilkinson 1983). The larger Caribbean sponge populations were reported to reflect higher concentrations of available organic matter (Wilkinson 1987). There is also an apparent correlation between the absence of phototrophic sponges in the Caribbean and more organic matter, but it is not possible to state that there is a causal relationship. The difference is not due to the non-existence of symbioses in the Caribbean, as the incidence of sponges with photosynthetic cyanobacterial symbionts is comparable in the 2 oceanic systems (Wilkinson 1987) and there are incidences of the same Genus occurring in both regions (Neofibularia irata on the GBR is a phototroph, whereas $N$. nolitangere is a mixotroph in the Caribbean)

The nutritional differences may be related more to different evolutionary patterns throughout the long period of separation rather than to the current levels of ambient primary productivity. During the past 3 to 5 million years, Caribbean reefs have been subjected to increased loads of sediments, nutrients and organic matter, particularly during periods of low sea level. As a consequence of these changes, many phototrophic species (corals and sponges) have probably become extinct as some of the reefs failed to keep up with subsequent sea level rise and 'drowned' (Hallock \& Schlager 1986). Phototrophic animals, particularly sponges, would be disadvantaged in waters carrying high loads of sediments, because of their flattened morphology and need to maintain open feeding canals. Pacific reefs have not been subjected to these gross changes in the nutrient environment and have continued to be more oligotrophic. This is considered to have favoured the evolution of more algal-animal symbiotic associations in the Pacific e.g. foraminifera (Hallock 1988). This trend of higher nutrient levels and higher levels of organic productivity in Caribbean reef regions is still evident (Koblentz-Mishke et al. 1970) and in parallel there are larger populations of sponges in Belize compared to the GBR.

There are 2 possible options to explain the differences in sponge populations relative to the content of organic matter in the surrounding water. In the first 
option, the biomass of heterotrophic sponges (excluding phototrophs) is directly proportional to the content of organic matter (Fig. 4a) with a consistent relationship between heterotrophic biomass and organic matter between oceans. Thus all populations of heterotrophic sponges on any coral reef (assuming that other factors are approximately equal, such as no increased predation) will occur on a continuum of biomass against available organic matter. The second option assumes that there is a direct relationship between heterotrophic biomass and organic matter within each oceanic region, but, the markedly different (taxonomically) sponge populations function differently in each ocean (Fig. 4 b). This option indicates that there will be a separation in the 2 curves for the 2 oceans.

Our data strongly support the first option (Fig. 4a) as there is an apparent direct relationship between the size of heterotrophic sponge populations and the amount of oceanic productivity in the respective region. There is ca 5 times higher biomass of heterotrophic (excluding phototrophs) sponges on the 3 Belize Barrier Reefs (mean of ca $730 \mathrm{~g} \mathrm{~m}^{-2}$ at peak population depth) than on the 12 reefs across the continental shelf of the GBR (mean, $134 \mathrm{~g} \mathrm{~m}^{-2}$ ). Similarly there is ca 3 times more primary productivity in the waters around the Belize reefs (GBR, 100 to $150 \mathrm{mgC}$ $\mathrm{m}^{-2} \mathrm{~d}^{-1}$; Belize, 250 to $500 \mathrm{mgC} \mathrm{m}^{-2} \mathrm{~d}^{-1}$; KoblentzMishke et al. 1970). Moreover, the sponges in the 2 oceanic regions have very similar respiration rates (Wilkinson 1987) indicating that there are no significant differences in either metabolic or filtration rates of Atlantic and Pacific sponges.

Birkeland (1988) has proposed that all coral reefs lie on an environmental spectrum from low nutrient, oligotrophic regions (e.g. mid-Pacific atolls) to high nutrient areas under the influence of strong upwellings (e.g. far east Pacific reefs). The location of a coral reef along this spectrum is probably the most significant factor in structuring the animal and plant communities on the reef and hence reef growth rates and productivity. At the lower end of the nutrient spectrum, reefs are dominated by animal-algal symbioses (corals, phototrophic sponges, tridacnid clams), whereas the symbioses are gradually replaced by heterotrophic animals, especially filter feeding sponges, ascidians and molluscs, as nutrient levels increase. This replacement is accompanied by a shift from increasing macroalgal dominance in medium to high nutrient regions, to phytoplankton dominance in high nutrient, upwelling areas. In some upwelling areas, the populations of filter feeders such as sponges are markedly reduced by large populations of predators (Birkeland 1987). Such a trophic shift was observed in Kaneohe Bay, Hawaii when increasing sewage pollution resulted in loss of coral cover and increases in macroalgae and filter feed-

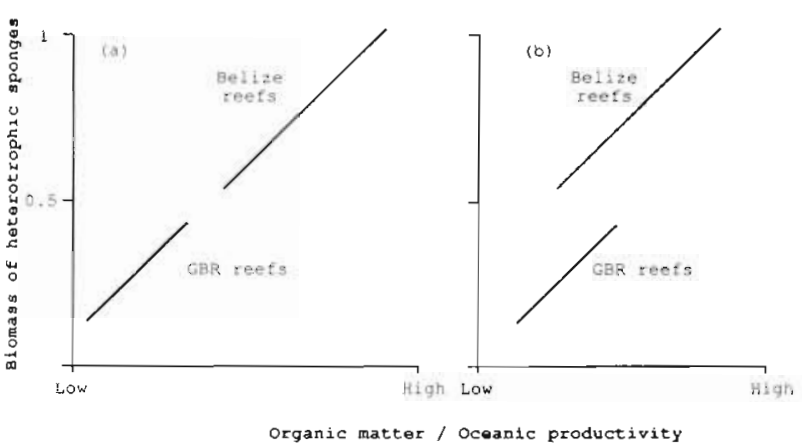

Fig. 4. Hypothetical graphs of heterotroph (including mixotroph, but excluding phototroph) sponge biomass at 15 or $20 \mathrm{~m}$ against a gradient of available organic matter and/or regional primary productivity. In Hypothesis (a) the sponge biomass for each reef is plotted on a continuum in which there is a direct relationship between available organic matter and the resultant population of heterotrophic sponges. In Hypothesis (b) it is assumed that there is a consistent relationship between heterotrophic sponge biomass and available organic matter within each barrier reef region, but that the relationships in the 2 oceans are unrelated. The organic matter axis has no scale as there are no reliable measures for either available organic matter or regional primary productivity at the scale of inter-reef differences for both of the 2 regions

ing animals, including sponges (Smith et al 1981). This process was effectively reversed when the sewage input was stopped and diverted into deep water.

The reefs for this study lie in the middle of this spectrum, encompassing almost the oligotrophic end (the Flinders Reefs in the Coral Sea) to a medium or medium-high nutrient position (the inner-shelf reefs of Belize and to a lesser extent, the inner-shelf reefs of the GBR). The sponge populations are considered to correlate directly with the position of the reefs on this nutrient spectrum. Belize sponge populations are large and almost exclusively heterotrophic, with consumption equivalent to 4 to $8 \%$ of the gross organic carbon produced on the reefs. Similarly, the populations on the adjacent oceanic reefs (Glovers) are large, indicating that there is sufficient organic carbon produced daily to sustain these large populations. In contrast, sponge populations on the GBR are ca 4 to 5 times smaller and those on the clean-water reefs (middle- and outershelf) consume about 10 times less organic matter. The net organic consumption by sponges on the adjacent oceanic reefs (Flinders) is very low, approximately 70 times less than the sponges on NE Glovers Reef (Fig. 3).

These marked differences in the size and nutritional strategies of the sponge populations between the 2 barrier reef systems provides further evidence for higher organic productivity in the Caribbean than in the Pacific. While this evidence is correlative, it supports other observations (Birkeland 1988, Thresher \& Brothers 1989, Vermeij 1989) suggesting that these differences are real and significant. 
The biomass of heterotrophic sponges at specific depths (e.g. 10 and $20 \mathrm{~m}$ ) is apparently directly related to the primary productivity (available organic matter) in the region of a coral reef. Any increase or variation in this biomass may be an indication of increased input of organic matter, such as organic pollution. This is evident in the larger populations of sponges around western Barbados, some parts of St. Croix and on the Florida Key reefs of the Caribbean (Wilkinson 1987). In parallel, the increased levels of organic pollution have resulted in stress and death to corals in the same area of western Barbados (Tomascik \& Sander 1986). We propose, therefore, that increases in the biomass of sponges may be an early warning indicator of chronic pollution stress on coral reefs.

Acknowledgements. This research was supported by a USAustralia Science and Technology Agreement grant, a grant from the Smithsonian Institution under the Caribbean Coral Reef Ecosystems Program supported in part by Exxon Corp. (CCRE contribution no. 291) to C.R.W. and the Australian Institute of Marine Science. We particularly thank Dr Klaus Rutzler and the staff on Carrie Bow Cay for their valuable help. Madeleine Nowak and Dr Ted Molinski ably assisted in the diving operations, often being buried deep in the fine sediment whilst searching for sponges. We thank the following for providing advice on drafts of this manuscript: David Barnes, Charles Birkeland, Miles Furnas, Anthony Hunt and several reviewers.

\section{LITERATURE CITED}

Birkeland, C. (1987). Nutrient availability as a major determinant of differences among coastal hard-substratum communities in different regions of the tropics. In: Birkeland, C. (ed.) Comparisons between Atlantic and Pacific tropical coastal marine ecosystems: community structure, ecological processes, and productivity. UNESCO Reports in Marine Science, No. 46, p. 45-97

Birkeland, C. (1988). Geographic comparisons of coral-reef community processes. Proc. 6th int. Coral Reef Symp., Townsville 1: 211-220

Cheshire, A. C., Wilkinson, C. R. (in press). Modelling the contribution of photosynthetic sponges to the energy budget of sponges on Davies Reef, Great Barrier Reef. Mar. Biol. (in press)

Colin, P. I. (1978). Caribbean reef invertebrates and plants. T. F. H. Publications, Neptune City, New Jersey

Hallock, P. (1988). Inter-ocean differences in algal-bearing foraminifera: a result of nutrient supplies? Proc. Gth int. Coral Reef Symp., Townsville 3: 251-255

Hallock, P., Schlager, W. (1986). Nutrient excess and the demise of coral reefs and carbonate platforms. Palaios 1 : 389-398

Highsmith, R. C. (1980). Geographic patterns of coral bioerosion: A productivity haypothesis. J. exp. mar. Biol. Ecol. 46 : 177-196

Kinsey, D. W. (1982). The Pacific/Atlantic reef growth controversy. Proc. 4th int. Coral Reef Symp., Manila 1: 493-498

Kinsey, D. W. (1983). Standards of performance in coral reef primary production and carbon turnover. In: Barnes, D. J. (ed.) Perspectives on coral reefs. Clouston, Manuka, A.C.T., p. $209-220$

Koblentz-Mishke, O. J., Volkovinsky, V V., Kabanova, J. G. (1970). Plankton primary productivity of the world ocean. In: Wooster, W W. (ed.) Scientific exploration of the South Pacific. Nat. Acad. Sci., Washington, D.C., p. 183-193

Porter, J. W (1974). Community structure of coral reefs on opposite sides of the Isthmus of Panama. Science 186: 543-545

Reiswig, H. M. (1974). Water transport, respiration and energetics of three tropical marine sponges. J. exp. mar. Biol. Ecol. 14: 231-249

Reiswig, H. M. (1981). Partial carbon and energy budgets of the bacteriosponge Verongia fistularis (Porifera: Demospongiae) in Barbados. Pubbl. Staz. zool. Napoli (I: Mar. Ecol.) 2: 273-293

Rosen, B. R. (1981). The tropical high diversity enigma - the corals'-eye view. In: Florey, P. L. (ed). Chance, change and challenge: the evolving biosphere. Cambridge Univ. Press, London, p. 103-129

Rutzler, K., Ferraris, J. D. (1982). Terrestrial environment and climate, Carrie Bow Cay, Belize. In: Rutzler, K., Mácintyre, I. G. (eds.) The Atlantic barrier reef ecosystem at Carrie Bow Cay, Belize. I. Structure and communities. Smithsonian Contributions to the Marine Sciences, No. 12, Smithsonian, Washington, p. 77-91

Smith, S. V., Kimmerer, W. J., Laws, E. A., Brock, R. E., Walsh T. W. (1981). Kaneohe Bay sewage diversion experiment: perspectives on ecosystem responses to nutritional perturbation. Pacif. Sci. 35: 279-402

Stoddart, D. R. (1974). Post-hurricane changes on the British Honduras reefs, re-survey, 1972. Proc. 2nd int. Coral Reef Symp., Brisbane 2: 473-483

Thresher, R. E. (1982). Interoceanic differences in the reproduction of coral-reef fishes. Science 218: 70-72

Thresher, R. E., Brothers, E. B. (1989). Evidence of intra- and inter-oceanic differences in the early life history of reefassociated fishes. Mar. Ecol. Prog. Ser 57: 187-205

Tomascik, T., Sander, F. (1986). Effects of eutrophication on reefbuilding corals. II. Structure of scleractinian coral communities on fringing reefs, Barbados, West Indies. Mar. Biol. 94: 53-75

Vermeij, G. J. (1978). Biogeography and adaptation: patterns of marine life. Harvard Univ. Press, Cambridge

Vermeij, G. J. (1989). Interoceanic differences in adaptation: effects of history and productivity. Mar. Ecol. Prog. Ser. 57 : 293-305

Victor, B. C. (1986). Duration of the planktonic larval stage of one hundred species of Pacific and Atlantic wrasses (family Labridae). Mar. Biol. 90: 317 -326

Wilkinson, C. R. (1982). Significance of sponges with cyanobacterial symbionts on Davies Reef, Great Barrier Reef. Proc. 4th int. Coral Reef Symp., Manila 2: 705-712

Wilkinson, C. R. (1983). Net primary productivity in coral reef sponges. Science 219: 410-412

Wilkinson, C. R. (1986). The nutritional spectrum of coral reef benthos. Oceanus 29(2): 68-75

Wilkinson, C. R. (1987). Interocean differences in size and nutrition of coral reef sponge populations. Science 236 : $1654-1657$

Wilkinson, C. R. (1988). Foliose Dictyoceratida of the Australian Great Barrier Reef. II. Ecology and distribution of these prevalent sponges. Pubbl. Staz. zool. Napoli (I: Mar. Ecol.) 9: 321-327

Wilkinson, C. R., Cheshire, A. C. (1988). Growth rate of Jamaican coral reef sponges after Hurricane Allen. Biol. Bull. mar. biol. Lab., Woods Hole 175: 175-179 
Wilkinson, C. R., Cheshire, A. C. (1989). Patterns in the distribution of sponge populations across the central Great Barrier Reef. Coral Reefs 8: 127-134

Wilkinson, C. R., Nowak, M., Austin, B., Colwell, R. R. (1981). Specificity of bacterial symbionts in Mediterranean and Great Barrier Reef sponges. Microb. Ecol. 7: 13-21

This review was presented by Professor C. E. Birkeland, Mangilao, Guam
Wilkinson, C. R., Trott, L. A. (1985). Light as a factor determining the distribution of sponges across the central Great Barrier Reef. Proc. 5th int Coral Reef Symp., Tahiti 5: $125-130$

Woodring, W. P. (1966). The Panama land bridge as a sea barrier. Am. Phil. Soc. Proc. 110: 425-433

Manuscript first received: November 29, 1990 Revised version accepted: August 3, 1990 